\title{
Governing Global Health Care: A Case Study of India vis à vis Switzerland's Novartis AG Regarding Patent of Gleevec
}

\author{
Novita Putri Rudiany \\ University of Groningen
}

\begin{abstract}
India has been acknowledged as the pharmacy of the world because of its developed pharmaceutical industries which produce many kinds of medicine for any diseases. However, this condition does not make the government close the opportunities for foreign manufactures to sell their products for the citizens. One of the foreign industries is the Switzerland's company, named Novartis AG, selling Gleevec, a leukemia-treating drug. In 2013, Novartis AG proposed to renew the patent of Gleevec because it has been updated from the last version of 1995, but Indian government rejected the patent rights of Gleevec based on the fact that the new Gleevec did not show any significant change for leukemia treatment. Based on the phenomenon, this paper examines about the dynamic of governing the global health with India as the case study. There are three perspectives that are used, those are: rejectionism, transnationalism and institutionalism. Each of the perspective focuses on the three discussions. It begins with the first part which explains the object that was being governed. The second part talks about the parties that have roles to govern. The third part elaborates on how those different parties governed the provision of the medicine production and distribution as the part of global health issue.
\end{abstract}

Keywords: Global health governance, India, Novartis AG, Gleevec, Patent Rights

India dikenal sebagai farmasi dunia karena industri farmasinya yang berkembang mampu memproduksi berbagai jenis obat untuk bermacam-macam penyakit. Namun, kondisi ini tidak membuat pemerintah India menutup kesempatan bagi manufaktur asing untuk menjual produknya kepada masyarakat India. Salah satu industri asing tersebut adalah perusahaan asal Switzerland, yakni Novartis A Gyang menjual Gleevec, obat untukleukemia. Pada tahun 2013, Novartis AG mengajukan pembaruan paten untuk Gleevec setelah formulanya diperbaruhi dari versi terakhir di tahun 1995, tetapi, Pemerintah India menolak permohonan tersebut berdasarkan fakta bahwa versi terbaru Gleevec tidak menunjukkan perubahan yang signifikan untuk pengobatan leukemia. Berdasarkan fenomena ini, tulisan ini mengkaji tentang dinamika dalam pengaturan global health dengan India sebagai studi kasus. Terdapat tiga perspektif yang digunakan, yakni: rejeksionisme, transnasionalisme dan institusionalisme. Masing-masing perspektif fokus pada tiga pembahasan. Pembahasan pertama mengkaji tentang obyek yang diatur. Bagian kedua membahas tentang pihak-pihak yang berperan dalam governance. Bagian ketiga mengelaborasi tentang bagaimana pihakpihak tersebut mengatur ketetapan produksi dan distribusi obat sebagai bagian dari isu kesehatan global.

Kata Kunci: Global health governance, India, Novartis AG, Gleevec, Hak Paten 


\section{Introduction}

According to the agreement on Trade-Related Aspects of Intellectual Property Rights (TRIPs) which was enacted in 1995 by the members of World Trade Organization (WTO), the pharmaceutical corporations have the rights to gain protection for its innovation of medicine. However, the implementation of TRIPs became a problem in most of the Global South, the developing countries. Because of the patent rights, people who suffered from heavy diseases, were unable to buy the medicine due to expensive prices. Therefore, there were many protests against this WTO provisions from not only local people in specific countries, but also transnationally through the international non-governmental organization. Their movement was fueled by the reason that medicine should have saved many lives, but the patent rights of medicine precisely killed people. They demand that the world regulation should consider about human rights aspects for those who live in developing countries.

One phenomenon raised to oppose the WTO regulations. The Republic of India rejected the Switzerland's Novartis AG effort to patent its leukemia-treating drug, Gleevec in 2013. This attempt had been conducted since 2006 as Novartis modified the elements to the updated version. India's decision was based on its 2005 new patent law. This new law enacted that the government of India would give the patent rights to the company, only if the company constituted brand new chemical substances or enhanced the therapeutic "efficacy" of known substance. The India Supreme Court argue that Novartis's new product is look alike its 1995 prior formula which had no significant change in therapeutic effectiveness. From then, India got criticized because its patent protection system for medicine is weak, and it could cause the global drug company investment rate decline. Yet, India did not change its regulation. India chose to develop the local pharmaceutical industry to produce the generic medicine. This policy was supported by the civil society as the people with cancer could get the medicine with reasonable price.

\section{Theoretical Framework}

There are three perspectives which are used to analyze this case. The first is rejectionism, the second is transnationalism and the third is institutionalism. These three perspective were chosen to show that 
within a global governance, especially regarding health care issue, there is no single argument which can comprehensively explain about the phenomenon. Each perspective has its own part to discuss the case from different point of views, especially about what to govern, who governs and how to govern.

In this problem, rejectionism seems the prominent perspective because the behavior of Indian government towards Novartis AG, is the main concern. Rejectionism is a critique of global governance, which could also be said to be the approach of those who reject a secular and capitalist world order (Sinclair 2012, 154). Rejectionism sees itself as a reform movement, determined to rekindle fundamental values and throw out many alien influences (Sinclair 2012, 155). In other words, this approach argues that there are some actors who do not cooperate well with the regulation that is applied globally. Rejectionist, also call themselves as nationalism, assume that global governance is impossible and destructive of state's role as agent of self-protection. This leads to the idea that the government or the state is the main actor. The government uses the value of the nation to protect the sovereignty of the country.

Transnationalism is the second approach to understand the issue between India and Novartis AG. This perspective is a way of understanding global governance that focuses not on international institutions or national states themselves, but on other agents (Sinclair 2012, 57). It argues that there is a room for a mass participation to involve in shaping global governance. Therefore, the main actor who stands for transnationalism is the global civil society. They are usually captured within the NGOs and in global social movements. The transnationalist identifies the neglected agents in the world politics and encourage a change, as a force for the good (Sinclair 2012 , 59). Even though the movements are sometimes invisible, but the aspiration from the civil society was clearly represented in the case of Gleevec patent rejection by some NGOs which have global advocacy networks.

The third approach is institutionalism. It can be neglected that international institution has a significant role to shape the global governance because of its capacity to stipulate a common agreement internationally. The issue turned into a problem when India was considered to disregard the TRIPs regulation by WTO. So that, 
institutionalism is used by concerning the institution as the central feature of global governance. Institutionalism assumes that policymaking and its implementation via intergovernmental institutions are central to the development of global governance (Sinclair 2012, 32). The regulation which is produced by the institution, is the way of thinking about the world problems to solve. The regulation might offer a solution to manage some crucial issue, such as global health care, but the global governance which is created, is not a universal objective, and many have skeptical view of the idea, from a variety of different political position (Sinclair 2012, 32).

\section{Multiple Actors of Global Health Care}

The behavior of the government of India clearly showed the point of view from Rejectionism approach. Rejectionism is quite clearly antagonistic to the global government, that antagonism is strongly felt and unmitigated (Sinclair 2012, 154). In this case, the government of India played a significant role in stipulating the provision that did not allow the Switzerland's Novartis AG to get its patent rights on Gleevec. There is one argument that answers why government of India has long been placed as the state that walk separately with the TRIPs regulation. The Indian pharmaceutical industries also contributed to the national income through exported product which reached $€ 3$ billion in 2006 as the demand for lowcost generic drugs was strongly on the rise, above all in the US, Europe and Japan (Deutsche Bank Research 2008, 5 in dbresearch. com). Since then, India had exported more medicine than its import. The large companies had adjusted their business model in order to become more competitive with the western companies in the field of patent-protected drugs. Based on this fact, India indeed has vital role in the field of global pharmacy. The second argument is that the pharmaceutical industry in India is considered as the third largest in the world. India is also called as the "pharmacy of the developing world" as it has become a leading supplier of generic medicines to many developing countries (Rehman 2011, 2). India provided the large quantities of drugs at cheap and affordable prices.

The second actor that also governs the global health care and was involved in the issue of Gleevec patent is the civil society. They were identified as group from The Cancer Patients Aid Association 
(CPAA), the Lawyers Collective HIV / AIDS Unit, The Delhi Network for Positive People (DNP+), International Medical Humanitarian Organization Medecins Sans Frontieres (MSF), CARE International and Oxfam International, and the church-based advocacy network, the Ecumenical Advocacy Alliance (Grainger 2007 in Oxfam.org.uk; MFS 2007 in mfsaccess.org). Those NGOs involved in giving different reactions to the government of India and the Switzerland's Novartis AG. The decision of Indian Supreme Court towards Novartis AG was supported by the NGOs because they hoped India will continue to supply medicine to the Global South, given the fact given the fact that developing countries and international agencies like UNICEF and the Clinton Foundation rely heavily on importing affordable drugs from India (Capdevila 2007 in atimes.com). However, the attempts for patent of Gleevec was condemned as the NGOs concerned that the strengthened patent protection would lead to increased drug prices, jeopardizing the access of the population of developing countries to affordable medicine and thereby impeding the fight against diseases of public health importance (WHO Drug Infromation 2005, 236).

The third actor is the WTO as platform to manage the health as common concern. This Bretton Woods institution plays an indirect yet vitally important role in the governance of health. The reason which could explain this WTO involvement in the global health system is the fact that trade and health have always been intrinsically linked through the spread and growth of both (Harman 2012, 51). Medicines have become a capital which means that the investment opportunities and production sites should not just located in an individual company's home country, but can be based in a variety of locations (Harman 2012, 52). TRIPs agreement under the WTO showed that there should have been common regulation about the acknowledgement and distribution of the drugs production. It aimed to promote the rights to health by ensuring investment, innovation and research into new and better medicines. In short, the TRIPs provided incentives to the companies to develop and guarantee the most needed drugs by the society. However, in the case of Gleevec, the function of WTO as global institution clearly pointed that institutionalism approach to the emergence of global governance had two significant weaknesses. First, the TRIPs agreement ignored deeper and longer-run causes for more proximate problems. The patent rights which could be gained by the drugs company would 
make the price of medicine become higher to value the researcher's ideas and efforts. This condition led to a wider gap between the developed and the developing countries regarding the capability to access them. The people in rich countries would not be affected of the increasing price because they are, either able to buy it or rarely suffer from such diseases. Yet, people in developing countries would feel difficult to get the medicine of their illness. This fact encompasses the second weakness of the institutionalism approach, that it neglects the basic inequalities, culture and traditional value (Sinclair 2012, 44).

The other party was the Switzerland's Novartis AG as the private company that could gain its patent of their products according to the TRIPs agreement. However, the company is more likely seen as the passive party which benefited the result of policy making process regarding the health care in global stage. Facing the government of India, Novartis AG almost had no impact in shaping the general regulation about the national right patent law. It also failed to gain support from international community, because of two reasons. First, the ambition to get new patent without significant change from its formula showed that the company only ran for their profit and ignored the simplicity access to public basic need. Second, the factor of India which opened the opportunity to the national pharmacy company to increase the development of generic medicine thus it could be accessible for the low-income society.

\section{Different Actors, Different Agendas}

Discussing the agenda that is being governed is actually could not be seen only from one point of view. As there were different actors involved, the agendas were also different. Therefore, it is important to examine them by seeing the actors through different perspective of global governance. Governing the global health could not be separated from the TRIPs agreement under WTO. As the member countries signed it, the pharmacy company could appeal the protection of their innovation through the patent rights. The demand of patent rights by Switzerland's Novartis AG for its Gleevec in 2006 to the government of India was influenced by a successful patent in 40 countries, including the United States (Bennet $2014,545)$ because they referred to the WTO regime. As the WTO 
is the primary international institution in this case, the things that were being governed could be analyzed through the perspective of institutionalism. The institutionalism approach assumed that the status quo -such as capitalism and private property- is preserved, but the chances of achieving success are enhanced (Sinclair 2012, 35). From this argument, it is clear that international institution tried to create fundamental norms which avoid upsetting the major stakeholder of the system, for example the property owners. Through the agreement, WTO knew that medicine had become important commodity which its global distribution should be managed. The innovation of medicine formula is valued as an asset thus must be granted by law. The rights are actually territorial by legal tradition, with each country or region establishing the terms under which it will define and protect such property. Yet, there was incongruence between the growing need for international exploitation of intellectual assets and the territorial, and often underdeveloped nature of rights to do so resulted in enormous pressures for systemic change (Maskus 1997, 2). This pressures generated a significant expansion of required minimum standards. In the case of health care, TRIPs encompassed the standardization of the medicine in order to ensure its quality, though was produced in different countries.

According to the assumption of the institutionalism perspective, the WTO governed one vital thing through the TRIPs. The concept of patent is to protect the ideas and profit. Many invention of the formula was done by the inventors from Multi-National Corporations (MNCs) which are originated in the developed countries. However, the formula could be modified by using the different -yet have same function- chemicals. This replica creation indeed needs the breakdown of the original formula. As the formula has been identified, other companies could make similar medicine -and possible to sell it with cheaper price. Thus, the main inventor, MNCs and also the investors or stakeholders became loss as they could bereave their markets. In this case, the patent will protect other companies (especially from the developing states) to breakdown the formula and create the cheaper drugs (Maskus 1996, 21). There should be compensation for any usage of the medicine, so it will prevent a huge loss of the MNCs. However, this governing process then headed to another problem at developing countries. The patent rights caused antagonism between the state and the companies. 
As the impact of the TRIPs, there are two different actors who critically responded. The case of Gleevec exposed the government of India as the center player in shaping the governance system in the field of global health. India came up with the decision not to follow the behavior of most countries which approved the patent rights demand from Novartis AG. The counter position of the government of India indicates the assumption of the rejectionism approach. Rejectionsim stands up with the state sovereignty and self-interest as its key features (Sinclair 2012, 156). Rejectionism is also closed with the behavior of rejecting a secular and capitalist world order. The pharmaceutical industry in India had been developed under the national government since 1960 by strengthening 5 state-owned companies to facilitate an independent supply of pharmaceutical products in the domestic market (Greene 2007, 2). India also tried to end its dependency to the foreign companies in the pharmacy field. India has concern to improve its population's access to medicine (Gabble and Kohler 2014, 1). Albeit the title of the new emerging country is addressed to India, this state is still having problem of poverty. Therefore, the people have difficult access to apply the health insurance. From the total population, only 5\% of Indian society who have private insurance (Mudur 2012, 2). The patent law and drug price control order were introduced in 1970 which clearly stated the commitment of the government to foster the development of indigenous Indian pharmaceutical industry and to guarantee that the India public had access to low cost drugs. Through this regulation, the Indian companies did not need to pay the licensing fee to reserve engineer or copy foreign patented drugs in order to produce bulk of generic medicine version.

By 2005, the share of foreign companies declined to less than $20 \%$ and the local firms were avowed as self-sufficient in the production of medicine. In the same year, India signed the TRIPs and should have amended its national law as the consequence. Signing the TRIPs agreement in WTO, India paid attention to the article 4 under the Doha Declaration which stated that the agreement can and should be interpreted and implemented in a manner supportive of WTO members' rights to protect public health and, in in particular, to promote access to medicines for all. This amendment was seen as the end of 36 years of protection for Indian pharmaceutical companies as it stipulated that Indian companies selling copycat drugs must pay foreign patent holders a "reasonable" royalty 
for copies sold in the Indian market (Greene 2007, 3). However, even though India revised its law, the main concern in the Patent Act 1970 still remains. As Ram $(2006,199)$ analyzed, the section 3(d) Patents Amendment Act 2005 stipulated that patents would not be available on the following grounds: the mere discovery of a known substance which does not result in the enhancement of the known efficacy of that substance; the mere discovery of any new property or new use for a known substance; the mere use of a known process, machine or apparatus unless such known process results in a new product or employs at least employs one new reactant. Through this section, the foreign company could not easily get the patent for its pharmacy products, which means that India still has high eagerness to maintain its self-reliance. The state has sovereignty to prioritize the health as one of public goods to be accessible for the people rather than giving the patent of the Gleevec to the Switzerland's Novartis AG. In sum, rejecting the appeal of Novartis AG indicated that two things were governed: first, to prove that India pharmaceutical industry is still competent and adequate to produce the generic form of the cancer medicine; second, to be a model to other developing countries of how government will take action to ensure the easiness to get the cheap medicine. In short, India as sovereign state focus on its function as agent of self-protection.

The other response came from the civil society. Their involvement brought the agenda of non-government parties. As the point of transnationalism perspective described, the efforts of (global) civil society, either through the NGO or mass movement, are the intervening variables that could give impact to the global governance. Therefore, the transnational interaction among these actors suggests a global political process which is not purely dominated by elites, but might be available to mass participation (Sinclair 2012, 57). In many cases, the civil society did what the Keck and Sikkink $(1998,13)$ called as "Boomerang pattern", that is the forces by bypassing the unresponsive state and seek allied in other states and in international institution to press the state for recognition of rights and attention to problems. But in this case, they acted differently as they precisely supported the state and challenged the world institution, WTO. This group of NonGovernmental Organizations (NGOs) presented in the joint statement and stated that the rejection by the government of India 
was a major victory for patients' access to affordable medicines in developing countries. Through the statement, they implicitly expected that other developing countries should have had the rigid law to protect the people, especially about the vital public good such as health care. Besides, the MSF also held petition which was signed by over 420.000 people from worldwide urging Novartis to drop the case because of the devastating impact Novartis' actions could have on access to essential medicines (Rehman 2012, 130). Therefore, this group of civil societies' movement could be marked as the force for the good. As the transnationalism approach assumed, this group brought out the facts that the TRIPs Agreement under WTO could not fit to the developing states with the low capabilities in accessing the health treatment. The agreement between the states in the international institution, which is WTO seemed neglected the social condition in the Global South. Thus, the transnational linkage and communication among them indicated that they tried to bring change towards a new system of global health care regulations which could give more consideration to the social conditions in the developing countries, especially for the citizens who experience the heavy diseases.

\section{Governing Global Health Care}

Examining the actors which govern and the objects which are governed in the term of global health care governance could be separated by using different perspectives. Yet, to discuss the method how this governance works, one could see it clearly as the "action-reaction" standpoint. First, it is important to explain the circumstances between the state elites, in this case is the WTO and the government of India. Both parties govern the global health care by using laws and regulations.

The function of formal institution is to regulate many of the social, political and economic problems traditionally within nationstates'; and it is effective to stipulate the way in which states should cooperate and compete with each other (Simmons and Martin 2001, 194). Based on that statement, TRIPs agreement is one of the regulation form, which is used to conduct the growing pharmaceutical industries in the world. The debate began when the development also occurred in the new economies such as 
India. The rise of generic manufacturing industries influenced the shape of global health and has been welcomed as a countervailing force against high-income countries of the global North (Harman and William 2013, 131). Therefore, medicine was valued as the commodity of trade and should be managed through the international law under WTO. As TRIPs was signed by the member states, the production of generic version of drugs could be limited because the local companies had no opportunities to break down the formula of the original one.

Another important instrument which was used by WTO to involve in the global health governance was the price of the medicine. As the medicine had become trade commodity, the price would fluctuate according to the supply and demand. However, WTO's regulation about the patent rights also influenced the drug pricing. The companies took the advantages of the regulation thus they could set prices of all goods and services (Mattingly 2012 in uspharmacist. com). Drug pricing is important, especially for the royalty of formula invention by the pharmacists. Some third-party contracts include a dispensing fee to help cover the pharmacy's professional and operational expenses. When the price is high, the pharmacy companies -which mostly come from developed countries- could ensure their profit. Noticing that WTO aims to allow the global market liberalization, the WTO creates competitive conditions for both state actors and non-state actors. The potential profits the monopolist stands to make from an essential single-source patented medicine should stimulate other firms to develop medicine that have the same health outcome because patents are granted for the chemical compound rather than the therapeutic indication (WHO 2012 in apps.who.int). This competition atmosphere is beneficial for the developed countries as the companies would pay higher tax to the government.

However, drug pricing by the companies put the developing countries in difficult situations. The poor manufacture countries will be abandoned from the competition as they could not produce similar formula. Thus, they have no choice except buy the product from the companies to fulfil their citizens' demand. Due to the high price of the medicine, government must intervene by wither subsidizing medicines or providing the free to the citizens. From this case, it is clear that some countries favour minimal regulation 
of pharmaceutical pricing, allowing suppliers, health sector, and patients to determine an equilibrium. Many people condemned the industrialized countries and their companies as they claimed that the quality of life in developing countries goes down as the drug price rises. Moreover, the unreasonable price should be paid by the patients only for a tactic called evergreening (reinventing old medications) which only give greater revenue for a pharmaceutical company.

Due to this condition, WTO action got reaction from the government of India. Its image as the "pharmacy of the developing world" became motivation to challenge the existing TRIPs agreement. The government precisely allows for greater access to medicines through its national law which had been existed since 1970. Amendment was completely done in 2005 with compliance to the TRIPs agreement, but the core of the law would never change. Indian government could limit the reach of product patent protection through its section 3(d) of the Patents (Amendment) Act of 2005 which essentially provides for a tougher standard for securing patent (Bennett 2014, 544). The Supreme Court of India enforced the Patent Law firmly by not allowing minor change of medicine to get patent, one of the example is this case of Gleevec which belongs to Switzerland's Novartis AG. This fact have been resisted by more powerful actors such as the United States, The European Union and China which tried to target for tighter regulation under a proposed Free Trade Agreement (Harman and William 2013, 131).

When the elites used the law to govern the global health care, the non-government entities used different method. As they have no sovereignty or power, they tried to influence the agenda by building network and triggered movements from the global communities. Many NGOs had strong concern to the public access to the medicine in order to ensure the society wealth. When the Novartis challenged the Indian Patent Office decision, MSF launched a campaign for the withdrawal of the case and ran with the help of MSF partners, also massive lobbying towards the US, EU and Canada to solicit support for the Indian patent law (Rehman 2011, 129). MSF and Oxfam also took part in a public hearing on "patients before patents" and the "Novartis case against the Indian law on patents," organized by Members of European Parliament (MEPs) (Gehardsen 2007 in ipwatch.org). Because of the NGOs efforts, the MEPs declared their 
grave concern and asked the Novartis AG to drop the case as the acknowledgement of the importance of access to cheap drugs by millions of people. From the picture, it is clear that the grass-root movements havesignificant power to influence the global governance.

\section{Conclusion}

The case of Gleevec patent rights between the government of India and Switzerland's Novartis AG in the field of global health care governance, put at least three main subject as the actors who governed. These three actors should be viewed by different perspectives (institutionalism, rejectionism and transnationalism), thus could lead us the clear map of the case. The root of conflict could be analyzed through the assumption of institutionalism, in which the international institution, WTO stipulated the international law (TRIPs agreement) to protect the ideas and profit for the stakeholders in the MNC which usually belongs to the developed countries. Regarding this, the companies endeavored to gain the patent rights for its products, in this case is Gleevec. However, the government of India rejected the demand. This could be examined using the rejectionsim perspective, as India implemented the self-protection to its pharmaceutical industries and people access to the cheap drugs by strengthening its national patent law. On the other side, the non-governmental actors also played a significant role by doing unusual behavior. In this case, NGOs did not oppose the state but challenge the institution. They were the force for the good and tried change towards a new system of global health care regulations to be more consider the social conditions of the people in Global South. There is no dominant perspective that could give more explanation to this case. Each perspective has their own part to describe the case comprehensively. 


\section{References:}

\section{Literature}

Bennett, William J, 2014. "Indian Pharmaceutical Patent Law and the Effects of Novartis Ag v. Union of India", Washington University Global Studies Law Review, Volume 13, Issue 3: The Legal Challenges of Globalization: A View from the Heartland (Symposium Edition).

Gabble, Ravinder and Jillian Clare Kohler, 2014. "“To patent or not to patent? the case of Novartis' cancer drug Glivec in India", Globalization and Health, 10:3.

Greene, William, 2007. “The Emergence of India's Pharmaceutical Industry and Implications for the U.S. Generic Drug Market", Office of Economics Working Paper U.S. International Trade Commission.

Harman, S. And D. Williams, 2013. Governing the World: Cases in Global Governance. London: Routledge.

Keck, Margareth E and Kathryn Sikkink, 1998. Activists beyond Borders: Advocacy Network in International Politics. Itacha, New York: Cornell University.

Maskus, Keith E, 1997. “The International Regulationof Intellectual Property" Paper Presented at the IESG Conference, "Regulation of International Trade and Investment," University of Nottingham, Nottingham, UK, September 12-14, 1997.

Mudur, G, 2012. "Final hearings begin in epic legal battle over Novartis drug in India". BMJ 345 (6257) :1-2.

Ram, Phrabu, 2006, “India's New 'TRIPs-Compliant' Patent Regime Between Drug Patents And The Right To Health", Chicago-Kent Journal of Intellectual Property.

Rehman, Hafiz Aziz ur, 2011. The Pharmacy of the Developing World: India, Patent Law and Access to Essential Medicines. Thesis of Doctor of Philosophy, Australian National University.

Simmons, Beth A and Lisa L. Martin. 2001. "International Organizations and Institutions", in Carlsnaes, Walter, Thomas Kisse and Beth Simmons, 2001. Handbook of International Relations, eds. Sage.

Sinclair, T, 2012. Global Governance. Cambridge: Polity. 
WTO Drug Information, 2005. "Access to Medicine: Intellectual Property Protection Impact on Public Health', WHO Drug Information vol. 19, No.3.

\section{Online Source:}

Capdcvila, Gustavo, 2007. 'Indian court rejects Novartis' drug patent suit' Asia Times online, 8 August 2007, online in http://www. atimes.com/atimes/South_Asia/IH08Df01 .html, accessed on 7 January 2017.

Deutsche Bank Research, 2008. India's Pharmaceutical Industry on Course for Globalization, online in https://www. dbresearch.com/PROD/CIB_INTERNET_EN-PROD/ PROD0000000000224095.pdf, accessed on 6 January 2017.

Gerhardsen, Tove, 2007. 'Opposition Gains Support Against Novartis Patent Lawsuit In India', Intellectual Property Watch, 15 February 2007, online in http:/ / www. ipwatch.org/weblog/ index. php? $p=535 \&$ res $=\&$ res $=1024 \& p r i n t=0$, accessed on 8 January 2017.

Grainger, Matt, 2007. 'Indian ruling against pharmaceutical giant Novartis a victory for public health' (Press Release August 6, 2007), online in http://www.oxfam.orG.uk/applications/ blous/pressoffice/2007/08/indian ruling against pharmace. html, accessed on 8 January 2017.

Medecins Sans Fronticres (MSF), 2007. 'Indian Court Ruling in Novartis Case Protects India as the 'Pharmacy of the Developing World' (Press Release August 6, 2007), online in http://www. msfaccess.oru/about-us/media-room/press-releases/indiancourt-ruling-novartis-case-protects-india-pharmacy, accessed on 8 January 2017.

World Health Organization (WHO), 2012. 'Pharmaceutical Pricing Policy', online in http://apps.who.int/medicinedocs/ documents/s19585en/s19585en.pdf, accessed on 8 January 2017. 